\title{
Solenogyne christensenii, comb. nov. (Asteraceae: Astereae), a new combination for a New Zealand species
}

\author{
Peter J. de LANGE ${ }^{1}$, Jian WANG ${ }^{2}$, John W. BARKLA ${ }^{3}$, Andrew MARSHALL ${ }^{1}$ \\ ${ }^{1}$ Unitec Institute of Technology, School of Environmental \& Animal Sciences \\ Private Bag 92025, Victoria Street West, Auckland 1142, New Zealand \\ p.delange@unitec.ac.nz \\ ${ }^{2}$ Queensland Herbarium, Department of Environment and Science, Brisbane Botanic Gardens \\ Mt Coot-tha Road, Toowong, Queensland 4066, Australia \\ jian.wang@des.qld.gov.au \\ ${ }^{3} 26$ Larkins Street, Dunedin 9010, New Zealand \\ mjbarkla@xtra.co.nz
}

de Lange P.J., Wang J., Barkla J.W., Marshall A. 2020. Solenogyne christensenii, comb. nov. (Asteraceae: Astereae), a new combination for a New Zealand species. Ukrainian Botanical Journal, 77(2): 73-80.

Abstract. The new combination Solenogyne christensenii (Petrie) de Lange, Jian Wang ter \& Barkla comb. nov. is validated for a New Zealand species originally published as Abrotanella christensenii Petrie. The species is described, illustrated and differentiated from similar and related taxa. The species is seriously threatened, being known with certainty only from the South Island of New Zealand where there is one extant population in Otago, though the species was also known historically from the type locality, Hanmer Plain, North Canterbury.

Keywords: Abrotanella, Asteraceae, Astereae, flora, new combination, New Zealand, Solenogyne, Solenogyne christensenii, taxonomy

Submitted 22 April 2020. Published 29 April 2020

де Ланге П.Дж., Ван Цзянь, Баркла Дж.В., Маршалл Е. 2020. Solenogyne christensenii, comb. nov. (Asteraceae: Astereae), нова комбінація для виду з Нової Зеландії. Украӥнський ботанічний журнал, 77(2): 73-80.

${ }^{1}$ Технічний університет УніТек

Окленд 1142, Нова Зеландія

${ }^{2}$ Гербарій Квінсленда, Брисбенський ботанічний сад

Тувонг, Квінсленд 4066, Австралія

${ }^{3}$ Данедін 9010, Нова Зеландія

Реферат. Нова комбінація Solenogyne christensenii (Petrie) de Lange, Jian Wang ter \& Barkla comb. nov. запропонована для виду з Нової Зеландії, який до того був описаний як Abrotanella christensenii Petrie. Подано опис та ілюстрації виду, вказані його відміни від подібних та споріднених видів. Цей вид перебуває під загрозою зникнення, оскільки він достовірно відомий лише з Південного острова Нової Зеландії, де збереглася лише одна популяція в регіоні Отаго, хоча раніше вид був також відомий з типового місцезнаходження на рівнині Хенмер у північній частині регіону Кентербері.

Ключові слова: Abrotanella, Asteraceae, Astereae, Solenogyne, Solenogyne christensenii, нова комбінація, Нова Зеландія, таксономія, флора

\footnotetext{
(C) 2020 P.J. de Lange, J. Wang, J.W. Barkla, A. Marshall. Published by the M.G. Kholodny Institute of Botany, NAS of Ukraine. This is an open access article under the terms of the Creative Commons Attribution License (http://creativecommons.org/licenses/by/4.0/), which permits use, distribution, and reproduction in any medium, provided the original work is properly cited
} 


\section{Introduction}

The genus of Solenogyne Cass. was established by Cassini (1828) for those plants that resemble Lagenophora Cass.; the latter is now recognized as a genus containing ca. 25 species occurring mainly in Australasia, South America, and southern and south-eastern Asia (Wang, Bean, 2019). Cassini (1816) initially published this as "Lagenifera", the spelling of which he later corrected to Lagenophora (Cassini, 1818), and that latter spelling was conserved (Art. 14.11 of the ICN: Turland et al., 2018) following the nomenclatural proposal by Nicolson (1996). Subsequently the two genera (Solenogyne and Lagenophora) were united by Hooker (1860) and Bentham (1867), and this was followed by Maiden and Betche (1916). It was Davis (1950) who revised and reinstated Solenogyne as a distinct genus. Her research was followed by Cabrera (1966) who further distinguished the two genera by differences in their achenes, e.g., those of Solenogyne are without a beak and glands.

As currently circumscribed, Solenogyne includes four species (Fig. 1, 2): three in Australia and one in Japan. At the time when the genus was erected, there was only one species recognised, S. bellioides Cass. described from near Port Jackson (modern Sydney area), New South Wales, Australia (Cassini, 1828). Exactly a century later, Koidzumi (1928) published S. mikadoi Koidz., the second species of the genus from Amamiohsima [Amami Ōshima, Amami Islands of the Satsunan islands group, Kagoshima Prefecture], Japan. Solenogyne gunnii (Hook.f.) Cabrera from Tasmania and $S$. dominii L.G.Adams from Australian Capital Territory, as the third and fourth members of the genus, were published by Cabrera (1966) and Adams (1979), respectively. Solenogyne mikadoi is now often treated as Lagenophora mikadoi (Koidz.) Koidz. ex H.Koyama (cf. Plants of the World Online http://powo.science.kew. org/taxon/249376-1), although this is not confirmed by phylogenetic studies (Nakamura et al., 2012; Sancho et al., 2015), or followed in Australasia (Schönberger et al., 2019).

New Zealand has three Solenogyne species, all treated as naturalised: S. mikadoi, S. dominii, and S. gunnii (Drury, 1974; Webb et al., 1988). Of these, S. mikadoi is extremely uncommon, while $S$. dominii is locally common, particularly around Christchurch and Banks Peninsula. Solenogyne gunnii is the most widespread species, often occurring as an urban weed in lawns and street side verges in the main centres of New Zealand.

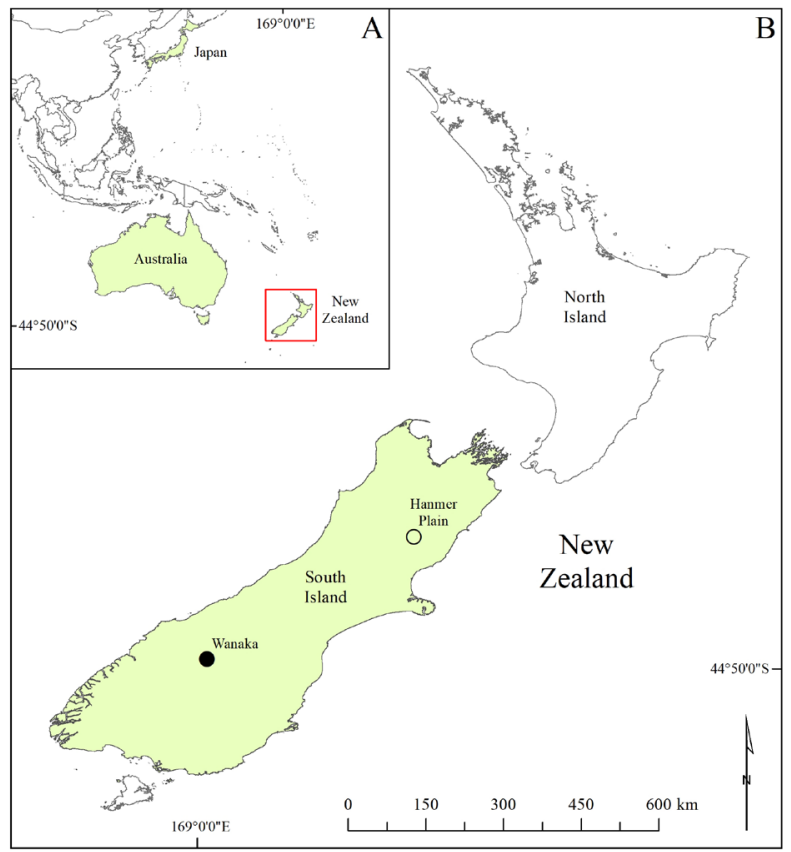

Figure 1. Distribution of the genus Solenogyne (A) and showing the two known locations for $S$. christensenii for the species in New Zealand (B), Hanmer Plain (the type locality, shown as an open circle because that population is now assumed to be extinct) and Wanaka, at the source of the Clutha River (black circle)

An enigmatic species of Abrotanella Cass., known only from the type collected by Charles E. Christensen from the Hanmer Plain, Amuri District, North Canterbury, was described by Petrie (1915) as A. christensenii Petrie. However, following critical examination of the type, this species was considered by Swenson (1993) to be conspecific with Solenogyne gunnii. There the matter of Abrotanella christensenii seemed to rest until an Asteraceous plant was discovered in a herbfield under kahikatoa (Leptospermum scoparium J.R.Forst. \& G.Forst. s. 1.) shrubland, near the outlet of Lake Wanaka, on the side of the Clutha River, Otago, by John Barkla in the early 2000s. That plant morphologically matched the type of Abrotanella christensenii; it was tentatively assigned to Solenogyne gunnii by Peter de Lange though it differed from that species with respect to its smaller overall stature, leaf colour, size and shape, and by having fewer disc florets. Specimens from this population were included in a phylogenetic study of Lagenophora (Sancho et al., 2015) where they were found to be sister to Solenogyne gunnii, thus further highlighting the possibility that these plants represented a fifth species of Solenogyne, the one endemic to New Zealand. 

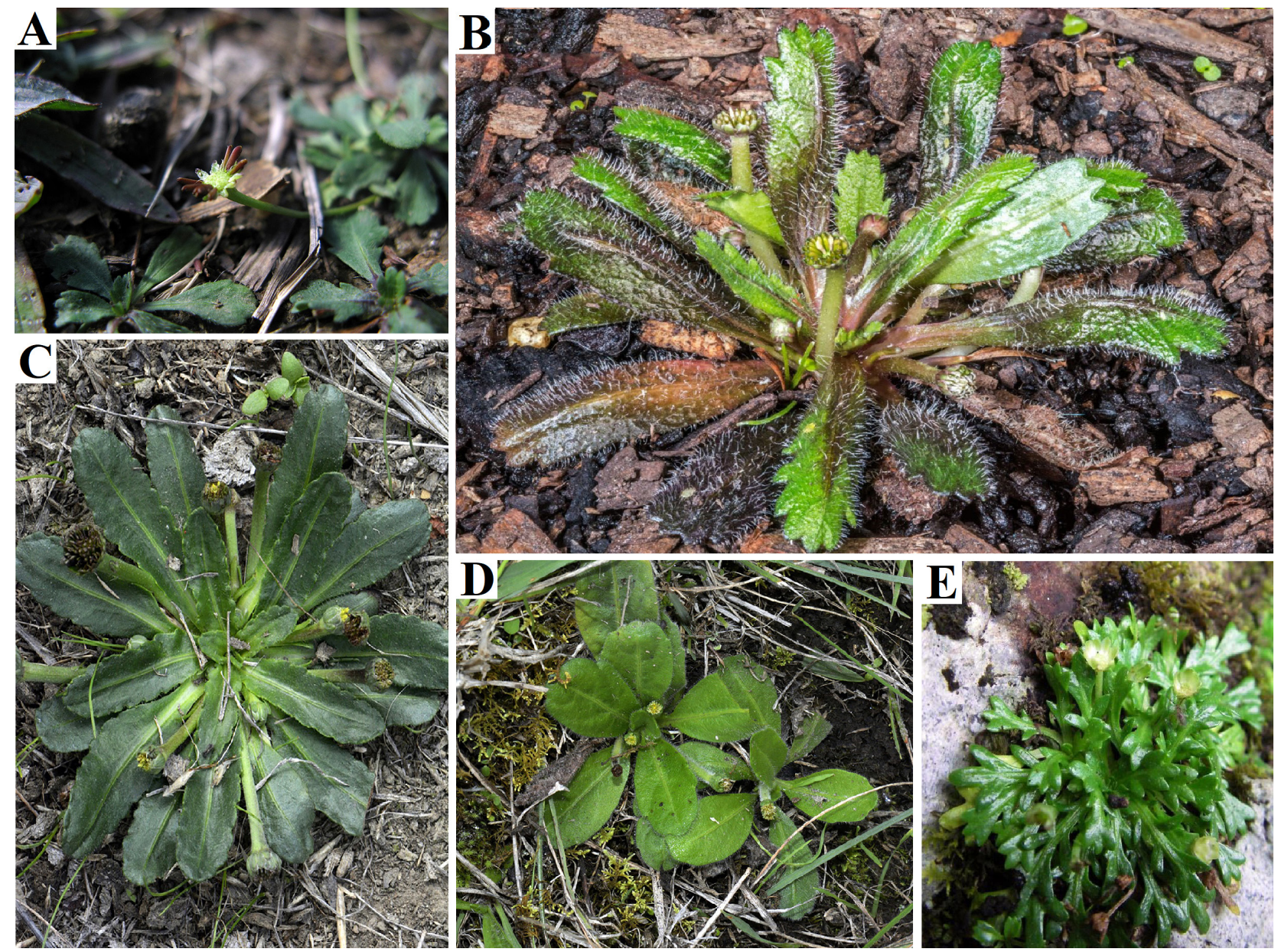

Figure 2. Solenogyne species. A: S. bellioides, Dungog, Australia (image: H. Rose). B: S. christensenii, cultivated plant, Stokes Valley, Lower Hutt, New Zealand (image: J.R. Rolfe). C: S. dominii, Cashmere Hills, Christchurch, New Zealand. D: S. gunnii, Cashmere Hills, Christchurch, New Zealand (images C, D: P. Enright). E: S. mikadoi, Kagoshima, Japan (image: Y. Uchiyama)

Following further examination of herbarium material and live plants, it is evident that Abrotanella christensenii, though allied to Solenogyne gunnii as Swenson (1993) thought, is a distinct species in its own right, and so a new nomenclatural combination in Solenogyne is made here.

\section{Materials and methods}

This article is based on the study of live plants cultivated in Dunedin, South Island, New Zealand, by John Barkla and the morphological examination of Solenogyne material at AK, BRI, CHR, MEL and WELT; herbarium acronyms follow Thiers (2020-continuously updated). All measurements are based on live plants, as well as dried material, except the dimensions of florets, in which material was reconstituted with boiling water.

\section{New combination}

Solenogyne christensenii (Petrie) de Lange, Jian Wang ter \& Barkla, comb. nov.

Basionym: Abrotanella christensenii Petrie, Trans. \& Proc. N.Z. Inst. 47: 51 (1915).

Type: New Zealand, South Island, Amuri, Hanmer Plains, March 1912, C.E. Christensen (holotype: WELT SP02098) (Fig. 3).

Note: Although Petrie (1915) did not specify a type, Cheeseman (1925) makes clear that there were only the two specimens held by Petrie, stating (p. 1005) "Only 2 specimens, which have been kindly lent [our emphasis] to me for examination by Petrie have been found", both specimens, are the same Christensen gathering that were forwarded by Leonard Cockayne (as became his practise when dealing with taxonomic matters: see Cockayne (1926), Thomson (1990), and de Lange (2019) 

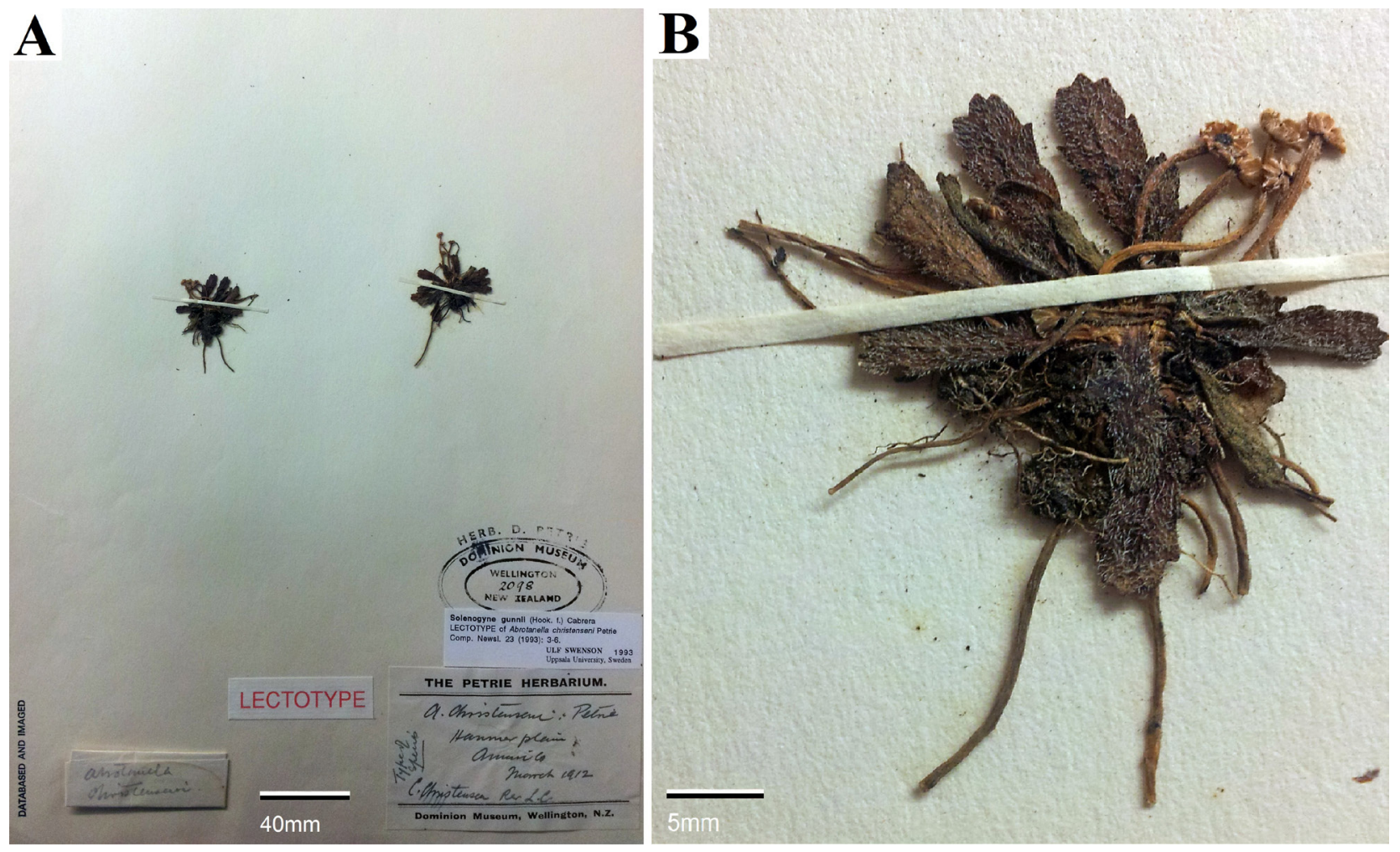

Figure 3. Holotype of Abrotanella christensenii Petrie, WELT SP02098. A: herbarium sheet. B: close up of one of the two plants mounted on the type sheet (image: P.J. de Lange)

for an account of Cockayne's stance on taxonomy) to Petrie. These are now mounted on the same sheet, WELT SP02098 (Fig. 3) held in the Petrie Herbarium, and labelled in Petrie's hand "Type Specm.". Therefore, Art. 9.1 of the ICN (Turland et al., 2018) applies, e.g., "A holotype of a name of a species or infraspecific taxon is the one specimen or illustration [bold type our emphasis here and thereafter] (but see Art. 40.4) either (a) indicated by the author(s) as the nomenclatural type or $(b)$ used by the author(s) when no type was indicated. As long as the holotype is extant, it fixes the application of the name concerned (but see Art. 9.15)". With respect to the number of specimens, Art. 8.2 applies ("for the purpose of typification a specimen.......may consist of a single organism, parts of one or several organisms, or of multiple small organisms") because the two specimens mounted on WELT SP02098 are part of the same gathering used by the naming author to describe Abrotanella christensenii. Nevertheless, Swenson (1993, p. 3) was under the impression that the two specimens referred to by Cheeseman (1925) were different collections held by different herbaria, perhaps misunderstanding Cheeseman's statement that Petrie "lent" him the specimens to study, stating "...that no more collections than the two cited by Cheeseman (1925) exist, i.e. the type specimens: C. Christensen, March 1912 (lectotype WELT). However, I have only been able to locate one of these sheets, the one deposited in Wellington (WELT), the second was presumably deposited in Auckland (AK) by Dr Petrie, but no type is held according to the herbarium". Thus he cautiously referred to WELT SP02098 as "Lectotype" presumably following the type statement of Allan (1961, p. 695) ("Type: W[ELT], C.E. Christensen") in the belief that two specimens had existed, and that one of those was now missing. However, Cheeseman on examining Petrie's two specimens (in fact, two plants) returned them to Petrie, and they now reside on the same herbarium sheet in his herbarium. Therefore, the type statements by Allan (1961) and Swenson (1993) can be taken as lectotype designations, but only if two or more syntypes or other original elements exist (or definitely existed). Since there are good reasons to believe that Petrie used only the two plants now mounted on the same sheet in WELT, that specimen in fact constitutes the holotype for his species name. 

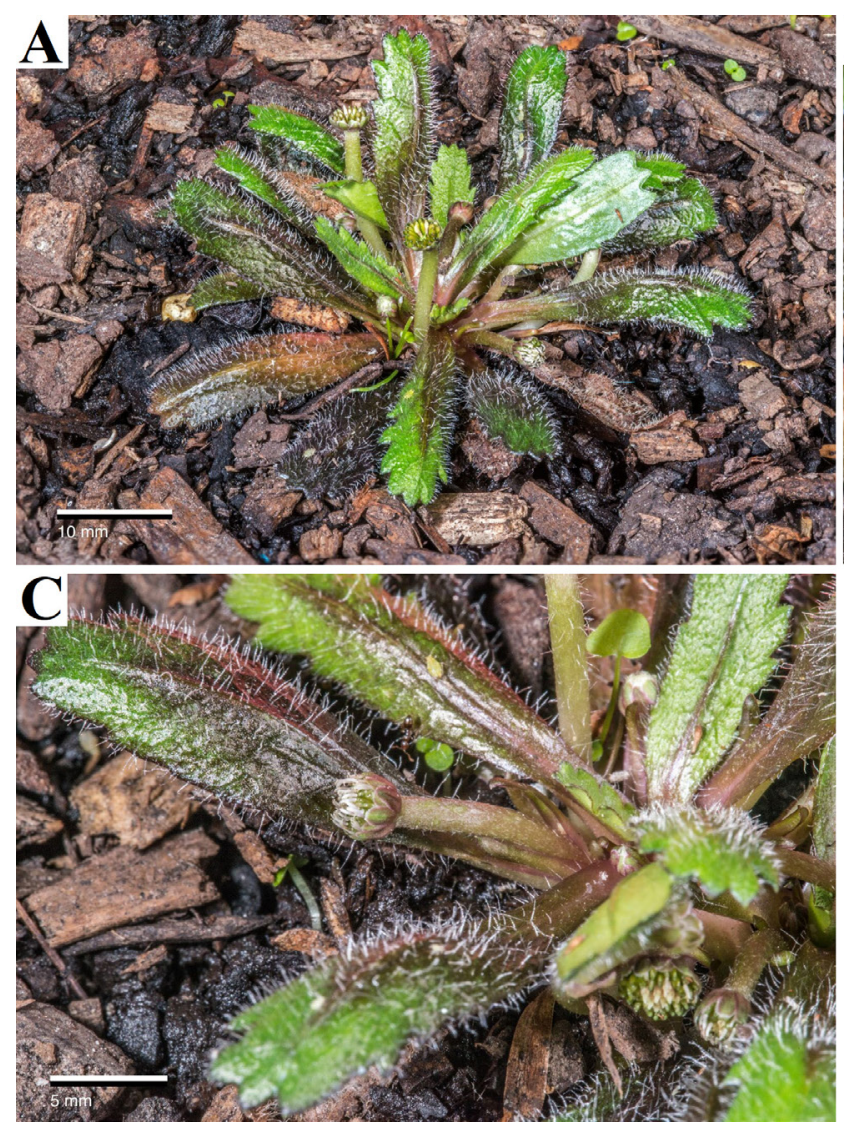

Description (Fig. 3, 4): Small perennial rhizomatous tufted herb up to $30 \mathrm{~mm}$ tall and $50 \mathrm{~mm}$ across; roots and rhizomes fibrous; stem very short (leaves in basal rosette); leaves and scapes firmly attached to stem and/ or rootstock. Leaves 15-25, oblanceolate, obdeltoid to cuneate, $10-20(-25) \times 5-8 \mathrm{~mm}(10-5 \times$ longer than wide), with a winged petiole-like base $8-10 \mathrm{~mm}$ long; leaf apex tridentate; leaf margins serrated (rarely repandsinuate), usually with $4-6$ teeth either side, each lobe $0.5-1.0 \mathrm{~mm}$ long; adaxial leaf surface glossy, initially green, maturing bronze-green or brown mottled, or maroon-brown; adaxial surface pilose, hairs patent eglandular, $0.3-1.8 \mathrm{~mm}$ long, 3-8 per $\mathrm{mm}^{2}$; abaxial leaf surface pale glossy green, \pm glabrescent; hairs present on young leaves, unevenly shedding with leaf maturation, eglandular, pubescent, \pm appressed, $0.4-0.8 \mathrm{~mm}$ long, 0-2 per $\mathrm{mm}^{2}$, hairs; both leaf surfaces papillate, papillae c. $0.01 \mathrm{~mm}$ long, more or less evenly distributed; leaf margins pilose, hairs eglandular patent 3-4 per $\mathrm{mm}^{2}$, $0.2-1.0 \mathrm{~mm}$ long; lateral veins slightly raised and usually visible adaxially, obscure abaxially. Scapes terete and smooth on fresh specimens, channelled on dry ones, 4-8 per tuft, each 5-20 $\mathrm{mm}$ long at anthesis, 10-30 mm long at fruiting stage, $1.5-2.5 \mathrm{~mm}$ diameter throughout; Украйнський ботанічний журнал, 2020, 77(2)

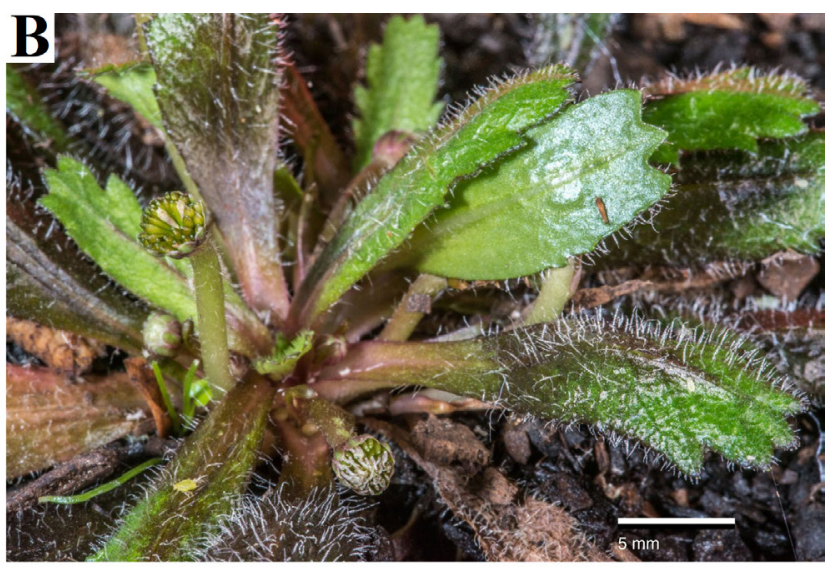

Figure 4. Cultivated plant of Solenogyne christensenii showing (A) growth habit, inflorescences, flowering and fruiting capitula (B, C) (images: J.R. Rolfe)

scape bracts 0 , or occasionally furnished with 1 , ovate to orbicular, chartaceous c. $1.5 \times 0.4 \mathrm{~mm}$ bract; scape indumentum including eglandular hairs $0.3-1.0 \mathrm{~mm}$ long, patent, spreading or mixed weakly appressed / retrorse; 1-6 hairs per $\mathrm{mm}^{2}$; and papillae to c. $0.01 \mathrm{~mm}$ long, scattered throughout the scape. Capitula 1.8-2.2 $\mathrm{mm}$ long, 2.8-3.0 mm diameter; involucral bracts 18-22 in 2 rows, glabrous or occasionally papillate along midrib on outer surface, ovate to broadly oblong, apex obtuse to rounded, margins pink, ciliate in upper distal $1 / 2-3 / 4$; outer bracts $1.2-1.6 \times 1.0-1.6 \mathrm{~mm}$, inner bracts $1.1-1.2 \times 0.9-1.0 \mathrm{~mm}$. Receptacle flat to slightly convex, $0.8-1.2 \mathrm{~mm}$ diameter. Ray florets tubular, creamy to pale pink, $18-20$ in 2-3 rows; tube $0.4-0.7 \mathrm{~mm}$ long, $0.1-0.12$ mm wide; style 0.5-0.8; stigma 2-branched c. $0.02 \mathrm{~mm}$ long. Disc florets $0-3$; corolla pale yellow, tubular, c.1 $\mathrm{mm}$ long, outer surface glabrous; corolla lobes 5 , deltate, c. $0.1 \times 0.1 \mathrm{~mm}$; stamens 5 , to c. $0.4 \mathrm{~mm}$ long; style c. 0.6 $\mathrm{mm}$ long; sterile ovary c. $0.3 \mathrm{~mm}$ long. Achenes glabrous, more or less flattened, narrowly obovoid, straight or slightly curved, $0.9-1.1 \mathrm{~mm}$ long by $0.3-0.5 \mathrm{~mm}$ wide excluding beak, uniformly yellow green, darkening to brown at maturity; achene edges smooth; achene beak 

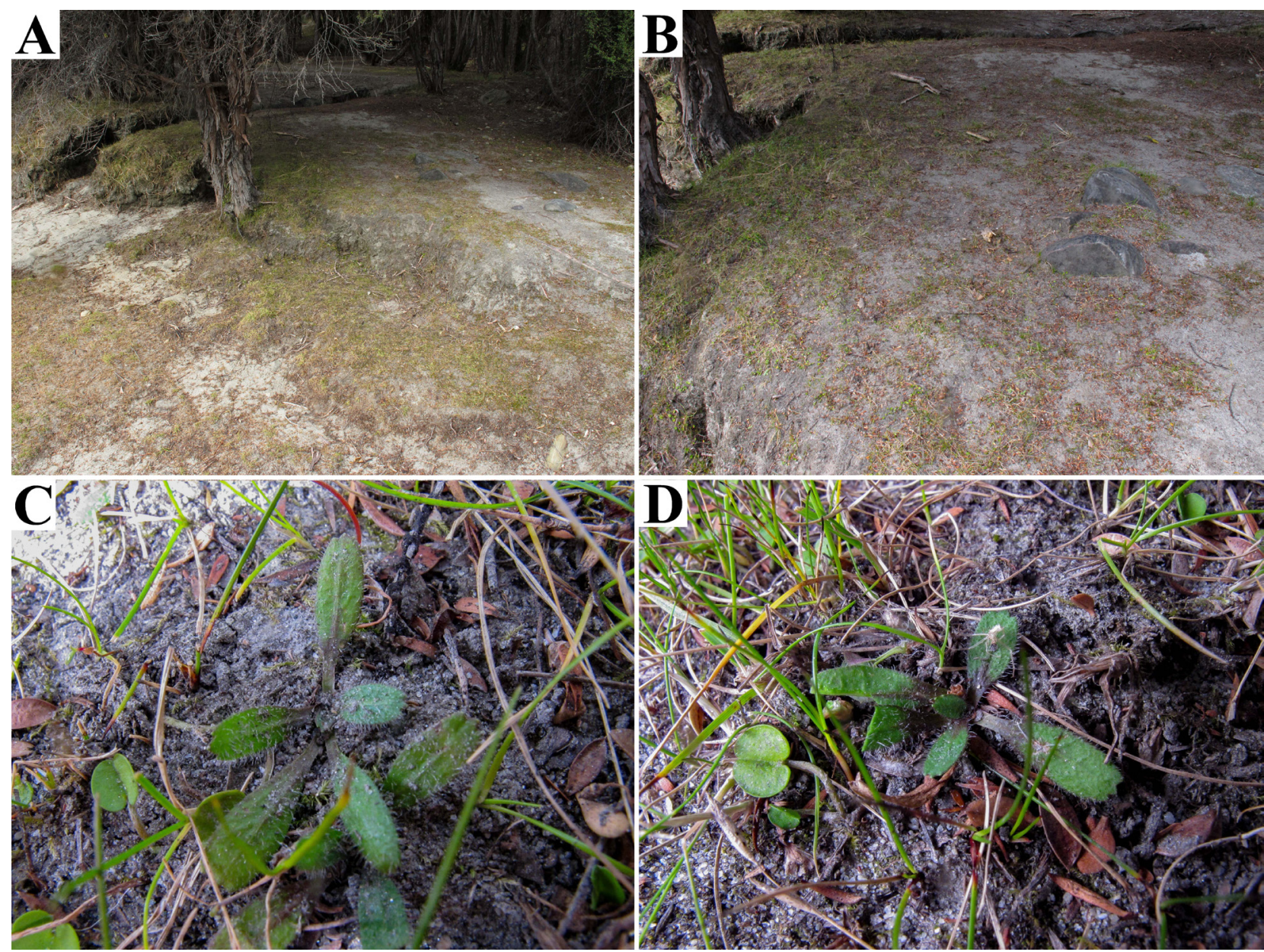

Figure 5. The habitat of Solenogyne christensenii on the side of the Clutha River, near Lake Wanaka, Otago, New Zealand. A: habitat on side of river bank adjacent a small walking track. B: close up of the habitat showing open herbfield in which the species grows. C, D: sterile young plants of Solenogyne christensenii (images: J.W. Barkla)

$0.1-0.2 \mathrm{~mm}$ long, without obvious annular collar at its apex, c. $0.1 \mathrm{~mm}$ diameter.

Additional specimens examined. New Zealand. Ex Cultivated, South Island, Otago, Clutha River, J.W. Barkla s.n., Mar. 2009, CHR 605697.

Etymology: Petrie (1915) named this species after Charles E. Christensen (1876-1938) who was the first person to collect this species, as Abrotanella christensenii, during his botanical exploration of the vegetation of Hanmer Plain, Amuri District, North Canterbury, New Zealand (Godley, 1994).

Distribution and habitat: Endemic to New Zealand where it is restricted to montane shrubland at approximately $280 \mathrm{~m}$ above sea level in the upper Clutha Valley of Otago (Fig. 1). At its only extant site (Fig. 5) it grows in tiny patches within a $25 \mathrm{~m}^{2}$ herbfield on silty riverbank under dappled shade provided by $2-4 \mathrm{~m}$ tall kahikatoa. Common associated native forbs include Dichondra brevifolia Buchanan, Galium perpusillum (Hook.f.) Allan, Colobanthus strictus Cheeseman, Centella uniflora (Colenso) Nannf., Leptinella sp., Pseudognaphalium luteo-album (L.) Hilliard \& B.L.Burtt (sensu lato), Ranunculus foliosus Kirk, Epilobium komarovianum H.Lév., Carex breviculmis R.Br., Carex resectans Cheeseman, and Isolepis sp. Common associated naturalized forbs and grasses include Prunella vulgaris L., Pilosella officinarum Vaill., Centaurium erythraea Rafn subsp. erythraea, and Agrostis capillaris L. (plant names are given mainly as accepted in de Lange \& Rolfe, 2010, and Schönberger et al., 2019).

In the past it has also been recorded from "bare spots in dry fescue [Festuca novae-zelandiae (Hack.) Cockayne] tussock steppe" from the Hanmer Plains (Petrie, 1915). 
Phenology: In the wild both flowers and fruits were observed mid-April. In cultivation, plants have been observed beginning to flower in January, with fruits evident a month later, with fruiting extending at least through to May.

Affinities: Solenogyne christensenii (Fig. 4) is of similar appearance to $S$. gunnii (Fig. 2, D), but differs by: the leaf size (usually 10-20 $\times 5-8 \mathrm{~mm}$ for $S$. christensenii; usually $20-100 \times 5-20 \mathrm{~mm}$ for $S$. gunnii) and leaf shape (usually oblanceolate, obdeltoid to cuneate for S. christensenii; narrowly obovate and obtuse for S. gunnii); the obtusely serrate leaf margins (sinuate to undulate for S. gunnii); the short and hirsute scape to 30 $\mathrm{mm}$ long in fruit (up to $100 \mathrm{~mm}$ long in fruit and woolly for S. gunnii); the fewer and shorter disc florets $(0-3$ and c. $1 \mathrm{~mm}$ long for $S$. christensenii; usually $7-9$ and c. $2 \mathrm{~mm}$ long for $S$. gunnii); the smaller achene size $(0.9-1.1 \mathrm{~mm}$ long for S. christensenii; 2.0-2.5 mm long for S. gunnii); and the flattened achene edges (achene edges more or less thickened for S. gunnii).

Solenogyne christensenii also resembles $S$. dominii (Fig. 2, C), from which it differs by: the pilose leaves (glabrate for $S$. dominii); smaller leaf size (usually 30-50 $\times 7-12 \mathrm{~mm}$ for $S$. dominii); the shorter scape (up to 70 $\mathrm{mm}$ long in fruit for $S$. dominii); the fewer and shorter ray flowers (18-20 and 0.4-0.7 mm long for $S$. christensenii; usually $35-60$ and $0.8-1.2 \mathrm{~mm}$ long for $S$. dominii); the fewer and shorter disc flowers (usually 10-14 and 2.0-2.5 mm long for $S$. dominii); the smaller achene size (2.0-2.5 mm long for $S$. dominii).

Conservation status: Solenogyne christensenii is an extremely uncommon species only known with certainty from one small population comprising less than 100 plants. Under the New Zealand Threat Classification System (Townsend et al., 2008), its conservation status, as Abrotanella christensenii, is listed as Nationally Critical qualified 'DP' [Data Poor] and 'EF' [Extreme Fluctuations] by de Lange et al. (2018).

\section{Acknowledgements}

Dr. Sergei Mosyakin provided encouragement and some advice on the preparation of this manuscript, and also facilitated the translation of the authors' names, addresses, abstract and keywords into Ukrainian. We thank Jeremy Rolfe for use of his images and the auspices of iNaturalist (www.inaturalist.org) and the contributors therein for permission to use their images of other Solenogyne species. The authors are appreciative of the comments made on the submitted manuscript by Dr. Filip Verloove, Meise Botanic Garden, Belgium.

\section{References}

Adams L.G. 1979. A review of the genus Solenogyne (Asteraceae) in Australia and New Zealand. Brunonia, 2: 43-65. https://doi.org/10.1071/BRU9790043

Allan H.H. 1961. Flora of New Zealand, vol. 1. Wellington: P.D. Hasselberg, Government Printer, liv + $1083 \mathrm{pp}$.

Bentham G. 1867. Lagenophora. In: Flora Australiensis, vol. 3. London: L. Reeve \& Co., pp. 506-508. Available at: https:/www.biodiversitylibrary.org/ item/41807\#page/515/mode/1up

Cabrera A.L. 1966. The genus Lagenophora (Compositae). Blumea, 14: 285-308. Available at: https://www.repository. naturalis.nl/document/565919

Cassini A.H.G. 1816. Aperçu des genres nouveaux formés, dans la famille des Synanthérées. Bulletin des Sciences par la Société Philomatique de Paris, [vol. of] 1816: 198-200. Available at: https://www.biodiversitylibrary. org/page/31774106\#page/615/mode/1up

Cassini A.H.G. 1818. Aperçu des genres nouveaux formés, dans la famille des Synanthérées. Bulletin des Sciences par la Société Philomatique de Paris, [vol. of] 1818: 30-34. Available at: https://www.biodiversitylibrary.org/ page/31583107\#page/254/mode/1up

Cassini A.H.G. 1828. Solenogyne. In: Dictionnaire des Sciences Naturelles (ed. F. Cuvier et al.), vol. 56. Strasbourg; Paris: F.G. Levrault \& Paris: Le Normant, 174-176. Available at: https://www.biodiversitylibrary. org/page/25316143\#page/192/mode/1up

Cheeseman T.F. 1925. Manual of the New Zealand flora. $2^{\text {nd }}$ ed. Wellington: Government Printer, xliv +1163 pp.

Cockayne L. 1926. Donald Petrie 1846-1925. Transactions and Proceedings of the Royal Society of New Zealand, 56: 8-10. Available at: http://rsnz.natlib.govt.nz/volume/ rsnz 56/rsnz 56_00_000080.html

Davis G.L. 1950. Revision of the genus Solenogyne Cass. Proceedings of the Linnean Society of New South Wales, 75 (3-4): 188-194. Available at: https://www. biodiversitylibrary.org/item/109152\#page/230/mode/1up

de Lange P.J. 2019. The ongoing slide to extinction of the enigmatic Chatham Island linen flax (Linum monogynum var. chathamicum). Trilepidea, 190: 3-7. Available at: https://www.nzpcn.org.nz/site/assets/files/0/51/314/ trilepidea_september_2019_final.pdf

de Lange P.J, Rolfe J.R. 2010. New Zealand indigenous vascular plant checklist. Wellington: New Zealand Plant Conservation Network, 131 pp. Available at: https://www. researchgate.net/publication/234077117_New_Zealand_ Indigenous_Vascular_Plant_List

de Lange P.J., Rolfe J.R., Barkla J.W., Courtney S.P., Champion P.D., Perrie L.R., Beadel S.M., Ford K.A., Breitwieser I., Schönberger I., Hindmarsh-Walls R., Heenan P.B., Ladley K. 2018. Conservation status of New Zealand indigenous vascular plants. 2017. New Zealand Threat Classification Series, 22: 1-82. Available at: https:// www.doc.govt.nz/Documents/science-and-technical/ nztcs22entire.pdf 
Drury D.G. 1974. A broadly based taxonomy of Lagenifera sect. Lagenifera and Solenogyne (Compositae Asteraceae) with an account of their species in New Zealand. New Zealand Journal of Botany, 12: 365-395. https://doi.org/10.1080/0028825X.1974.10428875

Godley E.J. 1994. Biographical Notes (15): Charles Edward Christensen (1876-1938). New Zealand Botanical Society Newsletter, 37: 12-13. Available at: http://www. nzbotanicalsociety.org.nz/newsletter/NZBotSoc-1994-37. pdf

Hooker J.D. 1860. Flora Tasmaniae, vol. I. Dicotyledones [Part 3 of: The botany of the Antarctic voyage of H.M. discovery ships Erebus and Terror in the years 1839-1843, under the command of Captain Sir James Clark Ross]. London: Lovell Reeve, cxxvii + 359 pp. + 100 pl. Available at: https:/www.biodiversitylibrary.org/ item/90337\#page/23/mode/1up

Koidzumi G. 1928. Plantae novae Amami-Ohsimensis nec non insularum adjacentium. Kagoshimaken Kyoiku Chosakai, 17. [Kagoshima: Education and Research Society of Kagoshima] 19 pp.

Maiden J.H., Betche E. 1916. Census of New South Wales Plants. Sydney: Government Printer, 216 pp. Available at: https://trove.nla.gov.au/work/11300918?q\&version $\mathrm{Id}=42165235$

Nakamura K., Denda T., Kokobugata G., Forster P.I., Wilson G., Peng C-I., Yokota M. 2012. Molecular phylogeography reveals an antitropical distribution and local diversification of Solenogyne (Asteraceae) in the Ryukyu Archipelago of Japan and Australia. Biological Journal of the Linnean Society, 105: 197-217. https://oi. org/10.1111/j.1095-8312.2011.01769.x

Nicolson D.H. 1996. Proposal to conserve the name Lagenophora (Compositae) with a conserved spelling. Taxon, 45: 341-342.

Petrie D. 1915. New native phanerogams. Transactions \& Proceedings of the New Zealand Institute, 47 [volume of 1914]: 48-59. Available at: http://rsnz.natlib.govt.nz/ volume/rsnz_47/rsnz_47_00_000950.html

Sancho G., de Lange P.J., Donato M., Barkla J., Wagstaff S.J. 2015. Late Cenozoic diversification of the austral genus Lagenophora (Astereae: Asteraceae). Botanical Journal of the Linnean Society, 177: 78-95. https://doi.org/10.1111/ boj. 12224
Schönberger I., Wilton A.D., Boardman K.F., Breitwieser I., Cochrane M., de Lange P.J., de Pauw B., Fife A.J., Ford K.A., Gibb E.S., Glenny D.S., Korver M.A., Novis P.M., Prebble J.M., Redmond D.N., Smissen R.D., Tawiri K. 2019. Checklist of the New Zealand Flora-Seed Plants 2019. Lincoln (New Zealand): Manaaki Whenua Landcare Research, 399 pp. https://doi.org/10.26065/ s3gg-v336

Swenson U. 1993. The identity of Abrotanella christensenii Petrie (Asteraceae). Compositae Newsletter, 23: 3-6. Available at: https://www.biodiversitylibrary.org/ item/48825\#page/4/mode/1up

Thiers B. 2008-onward. Index Herbariorum: A global directory of public herbaria and associated staff. New York Botanical Garden. Available at: http://sweetgum. nybg.org/science/ih (Accessed 24 April 2020).

Thomson A.D. 1990. A comparison of the approach to taxonomic botany by T.F. Cheeseman and L. Cockayne. In: History of systematic botany in Australasia - Proceedings of a symposium held at the University of Melbourne, 25-27 May 1988. Ed. P. Short. Canberra: Australian Systematic Botany Society Inc., pp. 235-238.

Townsend A.J., de Lange P.J., Duffy C.A.J., Miskelly C.M., Molloy J., Norton D.A. 2008. New Zealand Threat Classification System Manual. Wellington: Department of Conservation, 35 pp. Available at: https://www.doc.govt. nz/Documents/science-and-technical/sap244.pdf

Turland N.J., Wiersema J.H., Barrie F.R., Greuter W., Hawksworth D.L., Herendeen P.S., Knapp S., Kusber W.-H., Li D.-Z., Marhold K., May T.W., McNeill J., Monro A.M., Prado J., Price M.J., Smith G.F. (eds.) 2018. International Code of Nomenclature for algae, fungi, and plants (Shenzhen Code) adopted by the Nineteenth International Botanical Congress Shenzhen, China, July 2017. Glashütten: Koeltz Botanical Books. Regnum Vegetabile, 159: i-xxxviii + 1-254. https://doi.org/10.12705/Code.2018

Wang J., Bean A.R. 2019. A taxonomic revision of Lagenophora Cass. (Asteraceae) in Australia. Austrobaileya, 10(3): 405-442.

Webb C.J., Sykes W.R., Garnock-Jones P.J. 1988. Flora of New Zealand, vol. 4. Christchurch: Botany Division, Department of Scientific and Industrial Research (DSIR), lxviii +1365 pp.

Recommended for publication by S.L. Mosyakin 